\title{
Effect of number of prior reinforcements on social convergence
}

\author{
CARLA M. BEACH AND KENNETH E. LLOYD ${ }^{\prime}$ \\ WASHINGTON STATE UNIVERSITY
}

\begin{abstract}
In a Sherif type social convergence design five groups of Ss received $0,3,10,20$ and 40 reinforcements in Session 1. In Session $2 \mathrm{~S}$ and a collaborator whose responses differed by 8 in from the Ss' average in Session 1 responded together. The amount of response change from Session 1 to Session 2 was inversely related to number of reinforcements in Session 1 .

\section{Problem}

Sherif (1935) reported the classical experimental design for studying changes in responses of an $\mathrm{S}$ when tested alone and when tested in the presence of another $\mathrm{S}$ who also responded to the same class of stimuli. The stimuli were ambiguous, that is, many responses had similar probabilities of occurrence. The present study extended the work of Mausner (1954) who showed that reinforcement for responses in the alone session reduced response changes in the together session. $\mathrm{He}$ compared a group told they were right $82 \%$ of the trials with a group told they were wrong $82 \%$ of the trials. We compared five groups who were told only that they were right on $0,6,20,40$ and $80 \%$ of the trials.
\end{abstract}

\section{Method}

Fifty male undergraduate Ss served in 2 sessions one day apart. In Session 1 they estimated autokinetic movement for 50 trials alone. In Session 2 they estimated autokinetic movement for 50 trials alternately with a male collaborating $S$ whose estimates always averaged 8 in longer than those the $\mathrm{S}$ had made on his last 10 trials in Session 1. The collaborator (C) responded first on every trial. The $\mathrm{E}$ recorded all responses of both $\mathrm{S}$ and $\mathrm{C}$.

In the dark experimental room $S$ and $C$ sat $18 \mathrm{ft}$ from a $1 / 32$ in spot of light transmitted from a 7-watt bulb. The $\mathrm{E}$ sat in an adjoining room. A trial began when $E$ pressed a switch which turned on the autokinetic light and which sounded a buzzer. When S saw the light move he pressed a switch which started a timer which turned off the light $3 \mathrm{sec}$. later. The S then reported in inches how far the light had appeared to move. The $\mathrm{C}$ pressed a non-functional button.

Forty $\mathrm{Ss}$ were assigned to a group on the basis of their mean responses during the first 10 trials in Session 1 so as to match the group means. Group 3 was run later alone. In Session 1 the Ss were told that E would say "Right" when they gave correct estimates. In Session 2 they were told that $\mathrm{E}$ would no longer say "Right" since two Ss had to work together. The E never said "Right" during the first 10 trials in Session 1. She also never said "Right" to any $S$ in Group 0. For Groups 3, 10, 20, and 40 E said "Right" following every response after trials $47,40,30$, and 10 , respectively.

\section{Results}

Inspection of the scores from Group 3 in Session 1 indicated that they fell well within the range of the scores from the other four groups which were tested together. It seemed appropriate to analyze all 5 groups together. The Kruskal-Wallis one way analysis of variance by ranks was used for all tests of significance. The means for all groups in Trials 1-10 in Session 1 did not differ $(\mathrm{H}=2.36, \mathrm{df}=4, \mathrm{p}>.05)$. Similarily, the means for Trials 41-50 in Session 1 did not differ $(\mathrm{H}=3.23, \mathrm{df}=4, \mathrm{p}>.05)$. Although individual means differed widely the group means were similar in Session 1.

Difference scores (mean of Trials 51-100 in Session 2 minus mean of Trials 41-50 in Session 1) were computed for each $\mathrm{S}$ as a basis for assessing response changes from Session 1 to Session 2. These mean difference scores for Group 0,3,10, 20 and 40 were $4.14,3.14,1.77,2.02$ and 1.62 , respectively. The lower the difference score the less the change in the direction of C's responses. Groups receiving more reinforcements in Session 1 changed less in Session $2(\mathrm{H}=10.7, \mathrm{df}=4, \mathrm{p}<.05)$. A similar analysis of median difference scores was also significant $(H=11.42, d f=4$, $\mathrm{p}<$.05).

During Session $1 \mathrm{E}$ said "Right" on every reinforced trial regardless of what $S$ said. An alternative design would have required $S$ to respond within a certain range before $\mathrm{E}$ would say "Right," e.g., between 3 and 5 in. Then Ss would have differed in number of trials in Session 1, but a specific response class should have been conditioned. If so, then during Session 2 the frequency of this response class should have been directly related to number of reinforcements. The present data can provide an estimate of whether this would have happened. If saying "Right" was serving as a reinforcing stimulus then near the end of Session 1 the S's modal response was reinforced more than other responses. The frequency of this same modal response in Session 2 should be an estimate of its conditioned strength. Modal responses for trials 41-50 in Session 1 were obtained. The frequencies of these same responses in Session 2 were 22, 55, 114, 158 and 118 for Groups $0,3,10,20$ and 40, respectively. The analysis of variance was significant $(\mathrm{H}=10.89, \mathrm{df}=4$, $\mathrm{p}<.05)$. One factor reducing response change in Session 2 for groups receiving many reinforcements was the 
frequency with which the response reinforced in Session 1 continued to be emitted in Session 2.

\section{Discussion}

Reinforcements in Session 1 provided Ss with a basis for responding in Session 2. In session $2 \mathrm{C}$ served as another basis for S's responses. The extent to which $\mathrm{C}$ became such a basis depended upon Ss reinforcement history in Session 1. Undoubtedly C's rolealso involved a generalized history of reinforcement from outside the laboratory, viz., prior reinforcements for reducing differences in responses between $\mathrm{S}$ and others.

\section{Referenees}

Mausner, B. The effect of prior reinforcement on the interaction of observer pairs. J. abnorm. soc. Psychol., 1954, 49, 65-68.

Sherif, M. A study of some social factors in perception. Arch. Psychol., 1935, No. 187.

\section{Note}

1. The writers wish to thank the collaborator, Robert Schalock, for his special efforts. The study is part of a thesis submitted by the first author to the Graduate School of Washington State University in partial fulfillment of the Master of Science Degree. 